\title{
POLA ASUH ORANG TUA DALAM PENDIDIKAN AGAMA ISLAM TERHADAP ANAK PADA KELUARGA JAMA'AH TABLIGH DI KABUPATEN BUNGO PROVINSI JAMBI
}

\author{
Ana Rosyidatu Ummatin \\ Institut Agama Islam Yasni Bungo \\ Email: anarosyida@gmail.com \\ Dedi Yuisman \\ Institut Agama Islam Yasni Bungo \\ Email: dediyuisman@gmail.com
}

\begin{abstract}
The aim of this research is to describe the concept and implementation of parenting applied by parents on family of Tablighi Jamaat in educate their children, as well as the impact of missionary activity (khuruj) of the parents to the religious education of children aged 0 to 18 years. This research uses qualitative descriptive method by using data such as field notes, documentation, audio and video recordings and photographs or images. Data collected through observation, interviews and documentation. Data analysis technique through domain analysis, taxonomic analysis, componential analysis and analysis of cultural themes. Test the validity of the data is done by some of the techniques commonly used in qualitative research. The results of this study indicate that the concept of parenting in family of Tablighi Jamaat is part of the concept of Islamic parenting in general, which emphasis on religious aspect. Primary method of parenting is through the exemplary which comes from both of parents, held a ta'lim, take the children out (kburuj) to train preaching of Islam (dakwah), sending children to Islamic boarding school, and perform spritual effort (infirodi). The method of parenting has major impact for children in educate and practice of Islamic tenets. Parenting applied by parents in educating children in the family of Tablighi Jamaat is exemplary, ta lim, taking out of the children (khuruj), sending a children to Islamic boarding school, and perform spritual effort (infirodi). Parenting method has a major influence on the religious education of children. The success factors for religious education of children is faith, economy, seriousness, the educational background of the parents, and the environment.
\end{abstract}

Keywords : Parenting, Parent, Children, Family, Tablighi Jamaat.

\begin{abstract}
Abstrak
Penelitian ini bertujuan untuk mendeskripsikan konsep dan implementasi pola asuh yang diterapkan orang tua pada keluarga Jama'ah Tabligh dalam mendidik agama
\end{abstract}


anak, serta dampak aktivitas dakwah (khuruj) yang dilakukan orang tua terhadap pendidikan agama anak yang berusia 0 sampai 18 tahun.Penelitian ini menggunakan metode kualitatif deskriptif dengan menggunakan data berupa catatan lapangan, dokumentasi, rekaman audio dan video serta foto atau gambar. Pengumpulan data dilakukan melalui metode observasi, wawancara dan dokumentasi. Sedangkan teknik analisis data melalui analisis domain, analisis taksonomi, analisis komponensial dan analisis tema kultural. Uji keabsahan data dilakukan dengan beberapa teknik yang umum digunakan dalam penelitian kualitatif.Hasil penelitian ini menunjukkan bahwa konsep pola asuh dalam keluarga Jama'ah Tabligh merupakan bagian dari konsep pola asuh anak dalam Islam secara umum, dengan penekanan pada aspek pendidikan agama. Pola asuh utama orang tua dalam mendidik agama anak adalah melaui keteladanan kedua orang tua, mengadakan ta'lim rutin, mengajak anak-anak keluar (khuruj) untuk melatih berdakwah dan tabligh, menyekolahkan anak di pondok pesantren, dan melakukan usaha batin (infirodi). Pola asuh tersebut sangat berdampak bagi pendidikan dan pengamalan agama anak.Pola asuh yang diterapkan orang tua dalam mendidik agama anak dalam keluarga Jama'ah Tabligh adalah keteladanan, ta'lim rumah, mengajak anak-anak keluar (khuruj), menyekolahkan anak di pondok pesantren, dan melakukan usaha batin (Infirodi). Pola asuh ini sangat berdampak bagi pendidikan agama anak. Faktor keberhasilan pendidikan agama anak adalah keimanan, ekonomi, kesungguhan, latar belakang pendidikan orang tua, dan lingkungan.

Kata Kunci: Pola asuh, Orang tua, Anak, Keluarga, Jama'ah Tabligh

\section{A. Pendahuluan}

Pendidikan memainkan peranan yang sangat penting dalam membangun dan menumbuhkembangkan peradaban. Maju mundurnya suatu peradaban ditentukan oleh pendidikan. Bahkan, peradaban dan kebudayaan umat manusia tidak akan pernah muncul tanpa adanya pendidikan. Hal ini terjadi karena manusia terlahir ke dunia tidak memiliki daya dan ilmu yang membuatnya berkembang lebih maju, maka pendidikanlah yang membangun daya dan pengetahuan tersebut dalam jiwa manusia. Allah Swt. berfirman dalam Alqur'an surat An-Nahl/16 ayat 78 sebagai berikut:

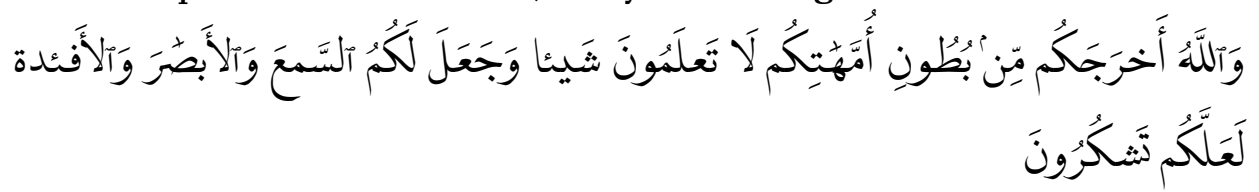


And Allah has extracted you from the wombs of your mothers not knowing a thing, and He made for you hearing and vision and intellect that perhaps you would be grateful.

Pendidikan dalam Islam dikenal dengan istilah tarbiyah, yang secara bahasa (lughawy) berasal dari bahasa Arab, yaitu dari asal kata kerja rababa. Dari kata kerja tersebut, lahirlah kata rabb sebagai sebutan bagi tuan, raja atau yang dipatuhi. Dari kata kerja tersebut juga, lahirlah kata tarbiyah yang bermakna pendidikan. Definisi tarbiyah (pendidikan) menurut istilah adalah membina atau menciptakan insan muslim yang memiliki akhlak baik dan sempurna dari segala aspek yang berbeda-beda, baik dari aspek kesehatan, akal, akidah, ruh keyakinan dan manajemen.

Perkembangan anak sangat dipengaruhi banyak hal, salah satunya adalah lingkungan dan pola asuh orang tua dalam mendidiknya. Pengasuhan (parenting) berasal dari bahasa Latin yaitu "parere" yang artinya membangun/mendidik. Pengasuhan (child rearing) diartikan sebagai pengalaman, keterampilan, kualitas, dan tanggungjawab sebagai orang tua dalam mendidik, merawat, dan mengasuh anak. Jerome Kagan, seorang psikolog perkembangan mengartikan pengasuhan sebagai penerapan serangkaian keputusan tentang sosialisasi: mengenai apa yang seharusnya dilakukan orang tua untuk menghasilkan anak yang bertanggung jawab, anak yang dapat berkontirbusi dalam masyarakat, serta bagaimana orang tua memberi respon ketika anak menangis, berbohong, marah, dan tidak berprestasi di sekolah.

Observasi awal penulis di kabupaten Bungo menggambarkan bahwa sebagian besar aktivis Jama‘ah Tabligh dan keluarganya memegang teguh prinsip dasar dalam berdakwah, yaitu dengan melakukan khuruj ke berbagai tempat, baik di sekitar daerah mereka berdomisili maupun ke daerah-daerah lain, bahkan sampai ke Luar Negeri, seperti India, Pakistan, Bangladesh maupun negara lainnya. Usaha dakwah ini dilakukan baik dalam waktu singkat maupun dalam waktu lama, baik oleh suami maupun istri serta melibatkan anggota keluarga lainnya. Dalam prakteknya, aktivitas khuruj membuat mereka harus meninggalkan pekerjaan pokok, keluarga, anak, istri maupun 
kegiatan sosial kemasyarakatan lainnya, termasuk mengasuh dan mendidik agama anak-anak dalam keluarga. Padahal orang tua memiliki tanggung jawab yang besar terhadap pendidikan anak dalam keluarga, terutama ketika mereka dalam usia 0-18 tahun. Karena masa tersebut adalah masa-masa emas pembentukan karakter dan pribadi anak agar menjadi pribadi yang baik dan bermanfaat pada masa-masa setelah usia tersebut.

Dalam pandangan keluarga Jama'ah Tabligh, anak adalah modal yang diberikan oleh Allah Swt. Barang siapa pandai menggunakannya dengan benar, maka akan mendapatkan keuntungan yang sangat besar. Barang siapa salah dalam menggunakannya, maka akan mendapat kerugian yang besar pula. Selain itu, anak merupakan amanah dari Allah Swt yang akan menjadi jaminan untuk masuk surga atau neraka.

Anak-anak yag dilahirkan adalah seperti Skain putih, bersih. Ibu dan bapaknyalah yang membentuk anak tersebut apakah ia akan menjadi seorang yang mentaati perintah Allah Swt ataukah sebaliknya. Setiap orang tua harus bercita-cita untuk menjadikan anaknya shalih dan shalihah. Oleh karena itu, mendidik anak dengan agama harus dimulai sejak anak itu masih dalam kandungan hingga akhir hayatnya dan dimulai dari dalam keluarga. Mendidik anak pada hakekatnya adalah mendidik seorang umat Rasulullah Saw, beserta keturunannya. Merusak anak berarti merusak seluruh umat nabi Muhammad Saw. oleh sebab itu, mendidik anak harus berdasarkan cara-cara yang diajarkan oleh Nabi Muhammad Saw, agar Islam dapat hidup secara sempurna dari generasi ke generasi hingga hari kiamat.

Menurut Thalib dalam bukunya Empat Puluh Tanggung Jawab Orang Tua Terhadap Anak, sebagaimana dikutip oleh Syaiful Bahri Djamarah, di antara tanggung jawab orang tua di terhadap anaknya adalah memberikan pendidikan akhlak, menanamkan akidah tauhid, membimbing dan melatih anak mengerjakan shalat, berlaku adil, memperhatikan teman anak, menghormati anak, mencegah dari perbuatan dan pergaulan anak, menjauhkan anak dari hal-hal porno, menempatkan anak dalam lingkungan yang baik, memperkenalkan kerabat kepada anak, mendidik bertetangga dan bermasyarakat. 
Temuan awal peneliti terhadap keluarga Jama'ah Tabligh di kabupaten Bungo menunjukkan bahwa, anak-anak dari keluarga Jama'ah Tabligh, khususnya pada usia 0-18 tahun cukup baik bila dilihat dari sisi pengamalan agama dan ketaatan terhadap nilai-nilai ajaran agama, seperti pelaksanaan shalat lima waktu, ketaatan kepada orang tua, ketaatan terhadap aturan berhijab, implementasi adabadab keseharian dan sunnah-sunnah Nabi Muhammad Saw, serta ajaran-ajaran lainnya.

Fenomena ini menjadi menarik untuk diteliti lebih jauh melalui penelitian akademis, guna melihat konsep dan implentasi pola asuh orang tua dalam mendidik agama anak pada keluarga Jama'ah Tabligh, khususnya di kabupaten Bungo propinsi Jambi.

\section{B. Pembahasan}

1. Kajian Teori

a. Pola Asuh Orang Tua

Pengasuhan (parenting) berasal dari bahasa Latin yaitu "parere" yang artinya membangun/mendidik. Pengasuhan (child rearing) diartikan sebagai pengalaman, keterampilan, kualitas, dan tanggungjawab sebagai orang tua dalam mendidik, merawat, dan mengasuh anak. Jerome Kagan, seorang psikolog perkembangan mengartikan pengasuhan sebagai penerapan serangkaian keputusan tentang sosialisasi mengenai apa yang seharusnya dilakukan orang tua untuk menghasilkan anak yang bertanggung jawab, anak yang dapat berkontirbusi dalam masyarakat, serta bagaimana orang tua memberi respon ketika anak menangis, berbohong, marah, dan tidak berprestasi di sekolah.

Pola asuh orang tua dalam keluarga berarti kebiasaan orang tua, ayah dan atau ibu, dalam memimpin, mengasuh dan membimbing anak dalam keluarga. Mengasuh dalam arti menjaga dengan cara merawat dan mendidiknya. Membimbing dengan cara membantu, melatih, dan sebagainya. Keluarga adalah sebuah institusi keluarga batih yang disebut nuclear family.

Keluarga sebagai institusi atau lembaga pendidikan informal ditunjukkan oleh hadits Nabi Saw. yang menyatakan bahwa keluarga 
merupakan tempat pendidikan anak paling awal dan yang memberikan warna dominan kepada anak. Sejak anak dilahirkan, ia menerima bimbingan kebaikan dari keluarga yang memungkinkannya berjalan di jalan keutamaan sekaligus bisa berprilaku di jalan kejelekan sebagai akibat dari pendidikan keluarga yang salah. Kedua orang tuanyalah yang memiliki peran besar untuk mendidiknya agar tetap dalam jalan yang sehat dan benar. ${ }^{1}$ Dalam sebuah hadits, Rasulullah Saw. menegaskan bahwa hitam putih seorang anak, beriman atau tidaknya seorang anak sangat tergantung kepada kedua orang tuanya.

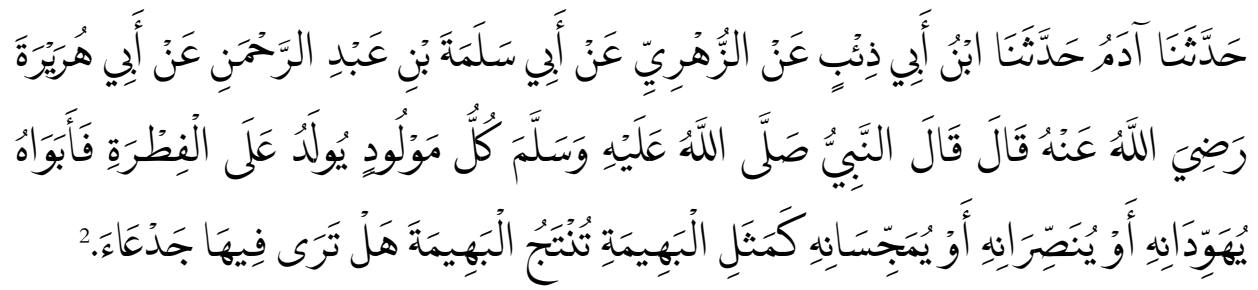

Artinya: Telah menceritakan kepada kami Adam telah menceritakan kepada kami Ibnu Abu Dza'by dari Az Zuhriy dari Abu Salamah bin 'Abdurrahman dari Abu Hurairah radliallahu 'anhu berkata; Nabi Shallallahu'alaihiwasallam bersabda: "Setiap anak dilahirkan dalam keadaan fithrah. Kemudian kedua orang tunyalah yang akan menjadikan anak itu menjadi Yahudi, Nashrani atau Majusi sebagaimana binatang ternak yang melahirkan binatang ternak dengan sempurna. Apakah kalian melihat ada cacat padanya? (HR. Bukhori, hadits no. 1385). ${ }^{3}$

Dalam perspekif Islam, pengasuhan anak merupakan usaha nyata dari orang tua dalam mensyukuri karunia Allah Swt, serta mengemban amanah-Nya sehingga anak menjadi manusia yang mandiri. Usaha nyata orang tua dimaksud adalah mengembangkan totalitas potensi yang ada pada diri anak, baik potensi rohaniah

${ }^{1}$ M. Roqib, Ilmu Pendidikan Islam: Pengembangan Pendidikan Integratif di Sekolah, Keluarga dan Masyarakat (Yogyakarta: PT. LKiS Printing Cemerlang, 2009), Cet. I, hal. 123.

${ }^{2} \mathrm{Abu}$ 'Abdullah Muhammad ibn Isma'l al-Bukhori, Al-Jami' Ash-Shahih (alQahirah: Mathba'ah Salafiah, 1400 H), Juz 1, hal. 424.

${ }^{3}$ Makna hadits dinukil dari software sembilan kitab hadits - Lidwa Pustaka. 
maupun jasmaniah. Potensi rohaniah meliputi potensi pikir, rasa dan karsa, sedangkan potensi jasmaniah meliputi potensi kerja dan sehat. Adapun tujuan pengasuhan orang tua terhadap anaknya menurut Alquran adalah untuk mendidik dan mengajarkan kepada anak agar menjaga hubungan vertikal dengan Allah Swt sebagai pencipta manusia dan kemudian memperbaiki dan menjaga hubungan horizontal dengan orang tua dan sesama manusia.

\section{a. Model-Model Pola Asuh Orang Tua}

Baumrind mengkategorikan gaya pengasuhan menjadi gaya pengasuhan tidak terikat (unengaged), serba membolehkan (permissive), otoriter (authoritative). Berbeda dengan Baumrind, Rohner mengkategorikan gaya pengasuhan menjadi gaya pengasuhan menerima dan gaya pengasuhan menolak berdasarkan teori penolakan dan penerimaan orang tua (parental acceptance rejection theory). Gaya pengasuhan lainnya dikemukakan oleh Gottman dan DeClaire mengkategorikan gaya pengasuhan ke dalam empat kategori yaitu gaya pengasuhan pengabai emosi (dismissing), gaya pengasuhan tidak menyetujui (disapproving), gaya pengasuhan laissez faire, dan pelatih emosi (emotional coaching).

\section{b. Kerelevansian Pola Asuh Orang Tua dengan Usia Anak}

Syaiful Bahri Dajamarah dalam bukunya Pola Asuh Orang Tua dan Komunikasi dalam Keluarga: Upaya Membangun Citra Membentuk Pribadi Anak, mengemukakan bahwa pola asuh orang tua berbanding lurus dengan mutu kepercayaan kepada anak. Secara teoritis, semakin meningkat usia anak, semakin kepercayaan orang tua kepada anak. Semakin tinggi kepercayaan orang tua kepada anak, semakin longgar pengawasan orang tua terhadap anak. Dengan demikian, usia anak memberikan pengaruh yang signifikan terhadap pola asuh yang dibangun oleh orang tua dalam mendidik anak. Kepercayaan berhubungan dengan soal pencitraan dan kontekstual.

\section{c. Peran Keluarga dalam Pendidikan Anak Menurut Islam}

Keluarga adalah batu bata pertama bagi pembinaan setiap masyarakat. Ia adalah langkah pertama untuk membina seseorang. Karena inilah, manhaj pendidikan moral dalam Islam harus dimulai sejak dini sekali. Pada dasarnya, ia merupakan asas yang harus 
dipertimbangkan bagi pembinaan keluarga yang kokoh dan harmonis. Sesungguhnya, pendidikan moral inilah yang menjamin terwujudnya keluarga Islam yang kuat, yang penuh warna rasa cinta, dan yang bahagia. Ia yang menjamin terbentuknya seorang manusia yang sehat tubuh, akal dan jiwanya. Dan ia pula yang menjamin terbentuknya masyarakat Islam yang kokoh dan bahagia.

Keluarga mempunyai peranan penting dalam pendidikan, baik dalam lingkungan masyarakat Islam maupun non-Islam. Karena keluarga merupakan tempat pertumbuhan anak yang pertama di mana dia mendapatkan pengaruh dari anggota-anggotanya pada masa yang amat penting dan paling kritis dalam pendidikan anak, yaitu tahuntahun pertama dalam kehidupannya (usia pra-sekolah). Sebab pada masa tersebut apa yang ditanamkan dalam diri anak akan sangat membekas, sehingga tak mudah hilang atau berubah sesudahnya.

\section{d. Jama'ah Tabligh}

Jama'ah Tabligh merupakan sebuah Jama'ah Islamiyyah yang dakwahnya berpijak pada penyampaian (tabligh) tentang keutamaankeutamaan ajaran Islam kepada setiap orang yang dapat dijangkau. Jama'ah ini menekankan kepada setiap pengikutnya agar meluangkan sebagian waktunya untuk menyampaikan dan menyebarkan dakwah dengan menjauhi bentuk-bentuk kepartaian dan masalah-masalah politik.Menurut Kamaruzzaman, gerakan Jama'ah Tabligh tidak membawa penafsiran baru terhadap ajaran Islam, hanya fokus pada implementasi sunnah Rasulullah saw. dan para sahabatnya dalam kehidupan masyarakat Islam, yang tidak keluar dari koridor aqidah, syariah, dan ma'rifat. Disebut Jama'ah Tabligh karena keberadaannya hanyalah untuk menyampaikan (tabligh) dakwah sebagaimana perintah Allah Swt., dan Rasulullah Saw.

Jama'ah Tabligh lahir karena adanya "kerusakan" mental umat Islam dan banyaknya masjid-masjid yang kosong. Ibadah-ibadah wajib sudah banyak ditinggalkan oleh umat Islam. Banyak orang mengaku beragama Islam, tetapi sebenarnya mereka telah terjatuh ke lembah kemusyrikan. Syeikh Muhammad Ilyas berpendapat, tidak ada jalan 
untuk memperbaikinya kecuali dengan kembali kepada ajaran Rasulullah Saw. ${ }^{4}$

Walaupun cukup berkembang dan telah diterima oleh hampri seluruh kalangan masyarakat, namun Jama'ah Tabligh tidak berada di bawah organisasi manapun, dan bukan merupakan organisasi resmi yang tercatat dalam sistem administrasi kepemerintahan. Hal ini dibuktikan karena tidak ada pada Jama'ah ini surat, akte ataupun sertifikat pendirian, juga tidak ada susunan pengurus dan kantor pengurus. Jama'ah Tabligh tidak memiliki Anggaran Dasar maupun Anggaran Rumah Tangga, layaknya organisasi resmi lainnya. ${ }^{5}$

Jama'ah Tabligh juga memfokuskan diri untuk mengajak kepada kebaikan (amar ma'ruf), tanpa kritik pada kemungkaran, bid'ah, khurafat dan sejenisnya seperti yang dilakukan oleh Salafi. Sebab, mereka yakin, jika dakwah dilakukan dengan cara mendobrak kemungkaran, orang akan lari dan mengalami kendala. Jika pribadipribadi telah diperbaiki, secara otomatis kemungkaran akan hilang. Menurut Jama'ah Tabligh, taqlid kepada mazhab tertentu adalah wajib, sedangkan ijtihad dilarang dengan alasan tidak ada ulama yang memenuhi syarat sebagai seorang mujtahid.

\section{e. Konsep Pola Asuh Anak Menurut Jamaah Tabligh}

Adapun konsep pendidikan adab dan akhlak bagi anak dalam keluarga Jama'ah Tabligh adalah:

1) Anak-anak harus diajari agar tidak memasuki kamar orang tuanya tanpa izin, terutama pada tiga waktu aurat, yaitu: sebelum waktu subuh, ketika waktu istirahat antara zuhur dan asar, dan setelah shalat Isya.

2) Hendaknya anak diajari untuk mengucapkan salam ketika masuk rumah sendiri dan rumah orang lain. Begitu juga ketika bertemu dan berpisah dengan seseorang.

${ }^{4}$ Abdul Aziz Dahlan (ed.), Suplemen Ensiklopedi Islam (Jakarta: Ichtiar Baru Van Hoeve, Cet. 9, 2003), hal. 266.

${ }^{5}$ Hasil observasi dan wawancara peneliti terhadap beberapa aktivis Jama'ah Tabligh membenarkan temuan tersebut. 
3) Biasakan anak untuk memberi, karena dengan cara ini ia akan menjadi dermawan.

4) Orang tua hendaknya mengajari anak dengan bijaksana agar tidak suka meminta kepada orang lain, karena ini merupakan kebiasaan buruk dan menyebabkan ia menjadi tamak dan iri.

5) Orang tua hendaklah bersikap tegas kepada anak dan jangan menyerah pada keinginan anak.

6) Orang tua tidak boleh selalu memenuhi apa yang diminta oleh anak karena ini adalah kebiasaan buruk dan dapat menyebabkan anak tidak hormat kepada orang tua.

7) Hendaklah orang tua jangan membiarkan anak-anak pergi ke rumah orang lain pada saat makan, karena akan merepotkan tuan rumah.

8) Tanamkan kebiasaan pada anak untuk makan berjamaah dan menerima apapun pemberian orang tua kepadanya (sifat qonaah).

9) Tanamkan dalam diri anak untuk membenci perkataan dusta.

10) Tanamkan kepada diri anak untuk berani mengakui kesalahannya dan meminta maaf kepada seseorang yang telah ia sakiti.

11) Tanamkan kepada anak agar tidak melakukan sesuatu dengan sembunyi-sembunyi karena biasanya anak hanya akan melakukan hal tersebut bila ia menganggap bila sesuatu perbuatan yang tidak baik.

12) Hendaknya orang tua jangan berbicara di depan anak dengan kata-kata dan bahasa yang kasar, tapi menggunakan kata-kata dan bahasa yang baik sehingga anak akan belajar menggunakan bahasa yang baik.

13) Orang tua hendaknya tidak membiarkan anak senang melihat hiburan-hiburan, seperti TV, videogame, play station, dan sebagainya, serta mencegah anak menggunakan uangnya untuk hal-hal tersebut.

14) Ajarkan anak agar ia berusaha menyelesaikan pekerjaannya sendiri, jangan biarkan mereka pasif dan malas, seperti menyiapkan dan membereskan tempat tidurnya sendiri.

15) Hendaklah selalu memberi semangat kepada anak-anak, jangan menunjukkan rasa kecewa di depan mereka saat orang tua membetulkan dan memperbaiki sikap dan perbuatan mereka. 
16) Hendaklah mengajarkan anak perempuan untuk mengerjakan pekerjaan rumah tangga, seperti menyapu, membersihkan perabotan, mencuci piring dan sebagainya.

17) Hendaklah orang tua tidak memihak secara tidak adil jika terjadi pertengkaran antara anak-anak tetapi selidikilah dengan teliti siapa yang salah.

18) Hendaknya orang tua tidak menghukum anak-anak dalam keadaan marah. Tunggu sampai marah reda dan berpikirlah tiga kali sebelum memberikan hukuman.

19) Setelah menghukum anak karena suatu kesalahan, hendaknya orang tua tidak segera mengajak anak bermain-main dan menampakkan rasa kasihan kepadanya karena itu akan menyebabkan anak kehilangan rasa takut pada orang tuanya.

20) Orang tua hendaknya jangan bertengkar di hadapan anakanaknya dan melibatkan mereka, karena itu merupakan tindakan yang bodoh.

21) Hendaknya semua perselisihan dan perbedaan dibicarakan secara rahasia di kamar tidur.

22) Orang tua hendaknya tidak mengikuti dan mengajarkan adat jahiliyah kepada anak-anaknya, seperti menanamkan kebencian dalam hati anak terhadap musuhnya dan lain-lain.

23) Orang tua hendaknya mengajarkan anak agar senantiasa menyambung silaturrahim walaupun terhadap orang yang memutuskan silaturrahim dengan dirinya.

24) Ajarkan anak-anak akhlak Rasulullah dan para sahabat. ${ }^{6}$

\section{Metodologi Penelitian}

a. Pendekatan Penelitian

Pendekatan yang dipergunakan dalam penelitian ini adalah pendekatan kualitatif deskriptif. Pendekatan kualitatif merupakan suatu paradigma penelitian untuk mendiskripsikan peristiwa, prilaku orang atau suatu keadaan pada tempat tertentu secara rinci dan

\footnotetext{
${ }^{6}$ Ibid.,hal. 97-98.
} 
mendalam dalam bentuk narasi. ${ }^{7}$ Menurut Nasution seperti yang dikutip oleh Sugiyono, penelitian kualitatif pada hakekatnya ialah mengamati orang dalam lingkungan hidupnya, berinteraksi dengan mereka, berusaha memahami bahasa dan tafsiran mereka tentang dunia sekitarnya. ${ }^{8}$ Pendekatan kualitatif digunakan karena permasalahan dalam penelitian ini belum jelas, holistik, kompleks, dinamis dan penuh makna. Selain itu, penelitian ini bermaksud untuk memahami situasi sosial secara mendalam, menemukan pola, dan teori. ${ }^{9}$ Pendekatan kualitatif bermanfaat untuk dapat lebih memahami setiap fenomena yang sampai sekarang belum banyak diketahui. ${ }^{10}$ Pada penelitian kualitatif deskriptif, peneliti hanya menggambarkan variabel saja tanpa membandingkan ataupun menghubungkan dengan variabel lain. ${ }^{11}$

\section{b. Situasi Sosial dan Subjek Penelitian}

Sebagai sebuah gerakan keagamaan di Indonesia, dakwah Jamaah Tabligh telah sampai di Kabupaten Bungo, yang merupakan salah satu kabupaten di propinsi Jambi, dan cukup berkembang serta mendapat respon yang beragam dari masyarakat. Namun, secara umum dakwah Jamaah Tabligh sudah dapat diterima oleh mayoritas umat Islam di kabupaten Bungo.

Penelitian ini dilakukan pada dua subjek, pertama, pada literatur-literatur yang membahas tentang pola asuh orang tua terhadap anak, khususnya dalam mendidik agama Islam. Hal ini dilakukan untuk mendapatkan gambaran konsep pola asuh orang tua terhadap anak dalam mendidik agama, baik pada keluarga Jamaah

${ }^{7}$ Djam'an Satori dan Aan Komariah, Metodologi Penelitian Kualitatif (Bandung: CV. Alfabeta, 2011), hal. 219.

${ }^{8}$ Sugiyono, Memahami Penelitian Kualitatif (Bandung: CV. Alfabeta, Cet. 9, 2014), hal. 205.

${ }^{9}$ Sugiyono, Metode Penelitian Pendidikan: Pendekatan Kuantitatif, Kualitatif, dan $R$ \& D (Bandung: CV. Alfabeta, 2006), hal. 399.

${ }^{10}$ Lexy J. Moleong, Metodologi Penelitian Kualitatif (Bandung: PT. Remaja Rosdakarya, Cet. XXV, 2008), hal. 7.

${ }^{11}$ Riduwan, Metode dan Teknik Menyusun Proposal Penelitian: Untuk Mahasiswa S1, S-2, dan S-3 (Bandung: CV. Alfabeta, 2010), hal. 8. 
Tabligh maupun selain keluarga Jamaah Tabligh. Kedua, pada keluarga Jamaah Tabligh yang berada di Kabupaten Bungo propinsi Jambi, untuk mendapatkan gambaran tentang implementasi pola asuh orang tua terhadap anak dalam mendidik agama pada keluarga-keluarga tersebut, serta hasil dari pola asuh tersebut terhadap pemahaman dan prilaku agama anak.

\section{c. Jenis dan Sumber Data}

Jenis data yang diungkapkan dalam penelitian ini bersifat skematik, narasi, dan uraian, serta bersifat penjelasan data dari informan baik lisan maupun tertulis. Selain itu, prilaku subjek yang diamati di lapangan juga menjadi data sebagai hasil dari penelitian. Berikut jenis-jenis data dalam penelitian ini:

\section{1) Catatan Lapangan}

Catatan lapangan menurut Bogdan dan Biklen sebagaimna yang dikutip oleh Lexy J. Moeloeng merupakan data tertulis yang memuat apa yang didengar, dilihat, dialami, dan dipikirkan peneliti pada saat mengumpulkan data dan merefleksikan data kualitatif. ${ }^{12}$ Jenis data ini didapatkan oleh peneliti dengan cara mencatat secara cermat, rinci dan ekstensif seluruh peristiwa yang benar-benar terjadi di lapangan selama penelitian.

2) Dokumen

Dokumen yang dimaksud dapat berupa catatan tulisan, gambar, ataupun berupa naskah yang berbentuk karya tulis yang di dalamnya menceritakan segala sesuatu yang berhubungan dengan masalah yang diteliti. ${ }^{13}$

3) Rekaman Audio dan Video

Rekaman yang dimaksud dalam penelitian ini adalah hasil wawancara peneliti dengan responden yang kemudian dideskripsikan dalam bentuk catatan untuk kemudian dianalisis menjadi hasil penelitian.

4) Foto atau Gambar

\footnotetext{
${ }^{12}$ Lexy, Op.Cit., hal. 208-209.

${ }^{13}$ Afifuddin, Op.Cit, hal. 118.
} 
Dalam penelitian ini, peneliti akan mengambil foto keluarga Jamaah Tabligh, baik orang tua, anak, lingkungan, ataupun hal lainnya yang berkaitan dengan masalah penelitian. Foto tersebut akan dianalisis sebagai penguat data yang diperoleh peneliti melalui teknik pengumpulan data yang lainnya.

\section{d. Teknik Pengumpulan Data}

Pengumpulan data dalam penelitian kualitatif melalui empat teknik utama, yaitu observasi partisipatif, wawancara mendalam, studi dokumentasi, gabungan ketiganya atau trianggulasi, ${ }^{14}$ dan teknik library research (studi perpustakaan). ${ }^{15}$ Adapun teknik pengumpulan data dalam penelitian ini adalah:

\section{1) Observasi Partisipatif}

Dalam penelitian ini, peneliti akan melakukan observasi dengan berinteraksi langsung terhadap keluarga Jamaah Tabligh, untuk mengetahui pola asuh orang tua terhadap anak-anaknya dalam mendidik agama. Selain itu, peneliti juga akan melakukan observasi terhadap lingkungan penelitian yang dapat mendukung objektivitas data penelitian.

2) Wawancara Mendalam

Wawancara dapat dilakukan dengan menggunakan pedoman umum wawancara yang mencantumkan isu-isu yang harus diliput tanpa harus menentukan urutan pertanyaan, atau dengan tanya jawab secara langsung. ${ }^{16}$ Wawancara dalam penelitian ini dilakukan terhadap informan yang dipilih secara purposif melalui snowball technique, yaitu informan pertama diminta untuk mengikuti orang lain yang dapat menunjukkan orang lain, dan seterusnya sampai dicapai taraf ketuntasan dan informasi yang diperlukan dianggap telah memadai. ${ }^{17}$

\section{3) Studi Dokumentasi}

\footnotetext{
${ }^{14}$ Sugiyono, Metode, hal. 309.

${ }^{15}$ Afifuddin, Op.Cit., hal. 131.

${ }^{16}$ Afifuddin, Op.Cit., hal. 131.

${ }^{17}$ Ibid.,hal. 129.
} 
Studi dokumentasi peneliti lakukan terhadap dokumen-dokumen yang berkaitan langsung dengan subjek penelitian berupa catatan, transkrip, buku, surat kabar, majalah, prasasti, notulen rapat, legger, agenda, dan sebagainya.

\section{e. Teknik Analisis Data}

Analisis data dalam penelitian kualitatif lebih banyak dilakukan bersamaan dengan pengumpulan data. Analisis data kualitatif menurut Miles and Huberman dilakukan secara interaktif melalui proses data reduction, data display, dan verification. Sedangkan menurut Spradley dilakukan secara berurutan, melalui proses analisis domain, taksonomi, komponensial, dan tema budaya. ${ }^{18}$

\section{f. Uji Keterpercayaan Data}

Pengujian keabsahan data dalam penelitian kualitatif meliputi uji kredibilitas data (validitas internal), uji dependabilitas (reliabilitas) data, uji transferabilitas (validitas eksternal/generalisasi), dan uji komfirmabilitas (obyektivitas). Namun yang utama adalah uji kredibilitas data melalui perpanjangan pengamatan, meningkatkan ketekunan, triangulasi, diskusi dengan teman sejawat, mengadakan member check, dan analisis kasus negatif. ${ }^{19}$ Pengujian keabsahan data dalam penelitian ini sangat penting karena pertanggungjawaban kepercayaan data terletak pada kriteria dan teknik pemeriksaan keabsahan data. ${ }^{20}$ Pengujian keabsahan data dalam penelitian ini dilakukan melalui pengujian kredibilitas, melalui teknik berikut:

1) Perpanjangan Pengamatan

Dalam penelitian ini peneliti akan turun ke lokasi penelitian dalam waktu yang cukup panjang guna mendeteksi dan memperhitungkan distorsi yang mungkin mengotori data. Perpanjangan pengamatan akan dapat menguji ketidakbenaran

${ }^{18}$ Sugiyono, Metode, hal. 401.

${ }^{19}$ Ibid., hal. 401-402.

${ }^{20}$ Lexy, Op.Cit., hal. 343. 
informasi yang diperkenalkan oleh distorsi, baik yang berasal dari diri sendiri maupun dari responden.

2) Meningkatkan Ketekunan

Selain itu, meningkatkan ketekunan dapat dilakukan dengan mengadakan pengamatan dengan teliti dan rinci secara berkesinambungan terhadap faktor-faktor yang menonjol. Kemudian menelaahnya secara rinci sampai pada suatu titik, sehingga satu atau seluruh faktor yang ditelaah sudah dipahami dengan cara yang biasa. Dalam proses ini peneliti dituntut agar mampu menguraikan secara rinci bagaimana proses penemuan secara tentatif dan penelaahan secara rinci dapat dilakukan.

\section{3) Triangulasi}

Triangulasi merupakan cara terbaik untuk menghilangkan perbedaan-perbedaan konstruksi kenyataan yang ada dalam konteks pengumpulan data tentang berbagai kejadian dan hubungan dari berbagai pandangan. Dengan kata lain bahwa dengan triangulasi, peneliti dapat memeriksa kembali temuannya dengan jalan membandingkannya dengan berbagai sumber, metode, atau teori. ${ }^{21}$ Dalam penelitian ini, triangulasi akan dilakukan dengan: 1) Mengajukan berbagai macam variasi pertanyaan; 2) Mengecek dengan berbagai sumber data; dan 3) Memanfaatkan berbagai metode agar pengecekan kepercayaan dapat dilakukan.

\section{Pembahasan Hasil Penelitian}

a. Konsep Pola Asuh Orang Tua Terhadap Anak Menurut Jama'ah Tabligh

Pengamatan peneliti terhadap keluarga Jama'ah Tabligh di kabupaten Bungo selama proses penelitian menunjukkan bahwa pendidikan agama menjadi prioritas utama, terutama bagi keluarga yang baru memiliki anak. Bahkan ada di antara keluarga Jama'ah Tabligh yang tidak menyekolahkan anaknya di sekolah formal dan

\footnotetext{
${ }^{21}$ Lexy, Op.Cit., hal. 323.
} 
hanya di lembaga pendidikan agama saja. Sedangkan bagi orang tua yang anaknya sudah terlebih dahulu mengenyam pendidikan formal sebelum bergabung dalam Jama'ah Tabligh, maka pendidikan tersebut tetap dilanjutkan dengan tetap memberikan pendidikan agama melalui metode lainnya. Hal ini didorong karena adanya keinginan agar anak-anak tersebut menjadi ahli agama.

Pola asuh yang yang dilaksanakan atau diterapkan dalam keluarga Jama'ah tabligh merupakan bagian dari prinsip-prinsip umum pendidikan anak dalam ajaran Islam. Keseluruhan pola pengasuhan tersebut didapatkan oleh para orang tua dari majelismajelis yang ikuti oleh mereka dan juga dari referensi yang telah ada. Khusus bagi para wanita, pola asuh ini diperoleh ketika mereka melaksanakan program masturah. ${ }^{22}$

\section{b. Implementasi Pola Asuh Orang Tua dalam Pendidikan Agama Islam Anak pada Keluarga Jama‘ah Tabligh di Kabupaten Bungo}

Dalam pandangan keluarga Jama'ah Tabligh, anak adalah modal yang diberikan oleh Allah Swt. barang siapa pandai menggunakannya dengan benar, maka akan mendapatkan keuntungan yang sangat besar. Barang siapa salah dalam menggunakannya, maka akan mendapat kerugian yang besar pula. Selain itu, anak merupakan amanah dari Allah Swt, yang akan menjadi jaminan untuk masuk surga atau neraka.

Berdasarkan pengamatan dan wawancara peneliti terhadap keluarga Jama'ah Tabligh di Kabupaten Bungo, ada beberapa pola asuh orang tua pada keluarga Jama'ah Tabligh dalam rangka mendidik agama anak. Pola asuh tersebut adalah melalui:

\section{1) Keteladanan;}

\footnotetext{
${ }^{22}$ Masturahadalah bentuk usaha dakwah di kalangan wanita dalam kelompok Jama'ah Tabligh. Kegiatan masturah dilakukan berdasarkan atas ketaqwaan, tertib dan dengan persyaratan yang ketat. Lihat: Abdurrahman Ahmad as-Sirbuny, Mudzakarah Masturat (Cirebon: Pustaka Nabawi, 2009), hal. 11. Pentingnya usaha dakwah melalui program masturah ialah karena:
} 
Mendidik dengan contoh (keteladanan) adalah satu metode pengasuhan yang dianggap besar pengaruhnya. Segala yang dicontohkan oleh Rasulullah Saw, dalam kehidupannya, merupakan cerminan kandungan Alquran secara utuh, sebagaimana firman Allah Swt:

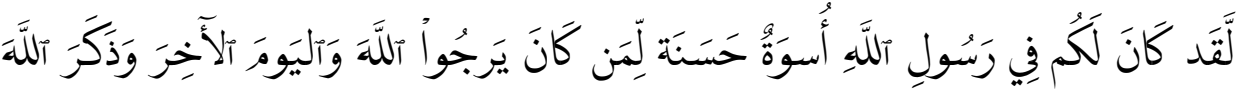

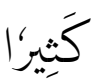

Artinya: Sesungguhnya telah ada pada (diri) Rasulullah itu suri teladan yang baik bagimu (yaitu) bagi orang yang mengharap (rahmat) Allah dan (kedatangan) hari kiamat dan Dia banyak menyebut Allah (QS. Al-Ahzab [33] : 21) ${ }^{23}$

Proses keteladanan dalam keluarga dapat dilaksanakan dengan mengajak langsung anak-anak untuk melaksanakan amalan atau ajaran agama, seperti mengajak shalat berjama'ah ke masjid, membacakan fadilah-fadilah amal maupun sirah (kisah) para sahabat setiap selesai shalat, mengikuti halaqah-halaqah atau majelis-majelis ilmu yang diadakan oleh kelompok Jama‘ah Tabligh.

2) Mengadakan ta'lim rutin dalam keluarga;

Ta'lim rutin merupakan sebuah sarana dalam mendidik agama anak secara khusus dan seluruh anggota keluarga secara umum. Dengan mengadakan ta'lim rutin, maka nilai-nilai agama dan sunnahsunnah serta adab-adab dapat disampaikan secara berkesinambungan bagi seluruh anggota keluarga. Bagi keluarga Jama'ah Tabligh, ta'lim rutin merupakan upaya nyata untuk menghidupkan sunnah di tengahtengah keluarga. Rasulullah Saw bersabda:

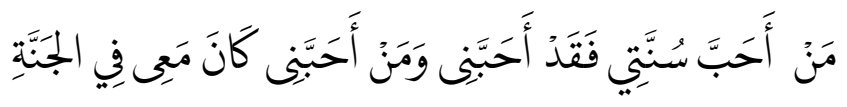

\footnotetext{
t.t), hal. 670

${ }^{23}$ Kementerian Agama RI, Alquran dan Terjemahnya (Surabaya: PT Al-Hidayah,
} 
Artinya: Barang siapa yang mencintai sunnahku maka dia cinta padaku, dan barang siapa cinta padaku, maka dia akan bersama-sama denganku di dalam Jannah.

Selain sebagai sarana pendidikan dan pengasuhan, ta'lim rutin dalam keluarga juga merupakan sarana bagi orang tua untuk bertukar pikiran dan mengingatkan anggota keluarga tentang rencana-rencana yang akan dilakukan oleh setiap individu anggota masyarakat. Ta'lim rutin juga merupakan sarana musyawarah keluarga dalam banyak hal, khusus masalah-masalah agama.

3) Mengajak anak-anak keluar (khuruj) untuk melatih berdakwah;

Berdasarkan kaedah atau ajaran para ulama Jama'ah Tabligh, orang tua boleh mengajak anak laki-laki yang berusia 15 tahun untuk keluar berdakwah (khuruj) selama tiga hari. Apa bila telah berusia 18 tahun, boleh diajak untuk 40 hari. Sedangkan anak perempuan yang telah berusia 18 tahun boleh diajak masturah tiga hari dengan disertai oleh mahramnya. ${ }^{24}$

Demikian besar dan agungnya keutamaan orang-orang yang keluar untuk berdakwah (khuruj) di sisi Allah Swt. keistimewaankeistimewaan tersebut telah mendorong para pengikut Jama'ah Tabligh di kabupaten Bungo untuk melakukannya, bahkan melibatkan anak-anak dalam usaha tersebut. Khuruj, selain sebagai sarana dakwah kepada Allah Swt. Firman Allah Swt dalam surat Ali 'Imran/3 ayat 104:

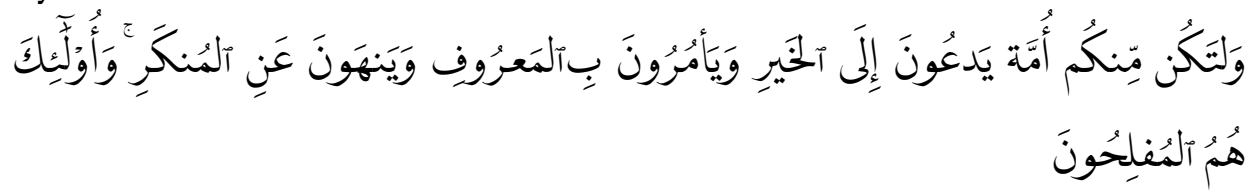

Artinya: Dan hendaklah ada di antara kamu segolongan umat yang menyeru kepada kebajikan, menyuruh kepada yang ma'ruf dan mencegah

${ }^{24}$ Kaedah atau ajaran ini dapat ditemukan dalam buku-buku yang menjadi pegangan bagi aktivis Jamaah Tabligh, diantaranya buku yang ditulis oleh Maulana Muhammad Ubaidillah yang berjudul Keutamaan Masturah: Usaha Da'wah di Kalangan Wanita Menurut Petunjuk Sunnah, yang diterbitkan oleh Pustaka Ramadhan, tahun 2010. 
dari yang munkar; merekalah orang-orang yang beruntung (QS. Ali 'Imran [3] : 104) $)^{25}$

4) Menyekolahkan anak di pondok pesantren; dan

Mengirim anak-anak ke pondok pesantren merupakan salah satu cara orang tua keluarga Jama'ah Tabligh dalam mendidik agama anakanaknya. Pendidikan pesantren selama terbukti dan dipercaya oleh sebagian masyarakat sebagai tempat yang ideal untuk mendapatkan ilmu agama, demikian juga dengan masyarakat di Kabupaten Bungo. Walaupun pendidikan ini tidak dilaksanakan langsung dalam keluarga, namun tidak dipungkiri bahwa ini adalah bagian dari upaya orang tua dalam mendidik agama anak. Beberapa keluarga Jama'ah Tabligh bahkan hanya menyekolahkan anaknya hanya di pondok pesantren, dengan harapan kelak anak-anak tersebut menjadi 'alim dan memahami agama dengan baik.

5) Usaha batin (infirodi).

Hasil penelitian menggambarkan bahwa selain adanya usaha zahir yang dilakukan oleh para orang tua, ada usaha batin sebagai bentuk kepasrahan dan keyakinan bahwa anak adalah milik Allah Swt, dan Dia-lah tempat bersandar dalam mendidik dan mengasuhnya. karena apapun usaha yang dilkukan oleh manusia tidak akan berhasil, jika tidak mendapatkan pertolongan dari Allah Swt. Tidak ada keberhasilan yang dicapai oleh manusia tanpa adanya campur tangan Allah Swt, apalagi dalam mengasuh dan mendidik manusia yang pemilik dan pembolak-balik hatinya adalah Allah Swt.

\section{c. Dampak Dakwah Jama'ah Tabligh terhadap Pendidikan Agama Islam Anak dalam Keluarga Jama'ah Tabligh di Kabupaten Bungo}

Dalam praktiknya, anggota Jama'ah Tabligh di Kabupaten Bungo juga melakukan aktivitas dakwah dengan menggunakan metode seperti yang dipaparkan diatas. Tidak sedikit juga dari anggota Jama'ah Tabligh yang melakukan dakwah dengan cara keluar (khuruj), baik tiga hari, 40 hari atau 4 bulan, bahkan 1 tahun.

${ }^{25}$ Departemen Agama, Op.Cit., hal.93 
Dakwah yang dilakukan oleh anggota Jama'ah Tabligh dengan segala metodenya telah memberikan dampak yang sangat positif bagi pendidikan agama Islam anak, khususnya dalam keluarga mereka. Metode dakwah yang dilakukan memberikan pengaruh yang signifikan bagi anak-anak dalam pemahaman dan pengamalan ajaran agama Islam. Seperti ketaatan dalam menjalankan ibadah, terwujudnya akhlak yang mulia, ketaatan kepada kedua orang tua, dan kegairahan dalam belajar agama.

\section{Penutup}

Berdasarkan hasil penelitian dengan mengunakan teknik wawancara, observasi dan dokumentasi terhadap pola asuh orang tua dalam pendidikan agama Islam anak pada keluarga Jama'ah Tabligh maka dapat diambil kesimpulan sebagai berikut:

Konsep pola asuh anak dalam pendidikan agama Islam anak pada keluarga Jama'ahTabligh merupakan bagian dari konsep pendidikan Islam secara umum, yang berdasarkan pada Alquran dan hadits serta contoh-contoh dari para ulama terdahulu yang menjadi panutannya. Keluarga Jama'ah Tabligh lebih menekankan pada pendidikan agama anak dari pada pendidikan formal yang bertujuan agar Islam secara sempurna dapat hidup dari generasi ke generasi, serta sunnah-sunnah Nabi Saw dapat hidup di tengah-tengah keluarga. Pengasuhan anak dalam keluarga Jamaah Tabligh dilaksanakan oleh kedua orang tua dengan melibatkan semua anggota keluarga. Prinsip-prinsip pola asuh dan pendidikan agama anak disampaikan melalui halaqah-halaqah atau majelis-majelis yang diadakan oleh kelompok Jamaah Tabligh. Sedangkan untuk para wanita disampaikan dalam program masturah.

Pola asuh orang tua dalam pendidikan agama Islam anak pada keluarga Jama'ah Tabligh dilakukan melalui: (a) Keteladanan, baik keteladanan yang berasal dari orang tua maupun dari anggota keluarga lainnya; (b) Ta'lim rutin dalam keluarga; (c) Aktivitas dakwah (khuruj fii sabiilillah); (d) Lembaga pendidikan pondok pesantren; dan (e) Usaha batin (infirodi).

Aktivitas dakwah (khuruj) yang dilakukan oleh anggota Jama'ah Tabligh cukup berhasil dan berdampak positif bagi pendidikan anak- 
anak dalam pembentukan karakter dan kepribadian yang Islami serta pengamalan ajaran-ajaran Islam. Aktivitas dakwah tidak mengurangi nilai-nilai pendidikan yang telah terpola dalam keluarga Jama'ah Tabligh. Faktor-faktor pendukung keberhasilan pola asuh dalam keluarga Jama'ah Tabligh adalah: (a) Keimanan; (b) Ekonomi; (c) Kesungguhan orang tua; (d) Latar belakang pendidikan orang tua; dan (e) Lingkungan.

\section{Daftar Pustaka}

Abdullah Naashih 'Ulwan. Tarbiyatul Aulaad Fil Islaam. t.t.p: Darussalam li ath-thibaa'ah wa an-Nasyr wa at-Tauzi', t.t, Juz. I - II.

Abu 'Abdullah Muhammad ibn Isma'l al-Bukhori. Al-Jami' Ash-Shahih. al-Qahirah: Mathba'ah Salafiah, Juz 1, 1400 H.

Ahmad Syafii Mufid. "Faham Islam Transnasional dan Proses Demokratisasi di Indonesia”. Harmoni: Jurnal Multikultural \& Multireligius, Vol. III, No. 31, April-Juni 2009.

Ani Siti Anisah. "Pola Asuh Orang Tua dan Implikasinya Terhadap Terhadap Pembentukan Karakter Anak". Jurnal Pendidikan Universitas Garut, Vol. 5, No. 1, 2011.

An-Naddhr M. Ishaq Shahab. Khuruj Fi Sabilillah: Sarana Tarbiyah Ummat Untuk Membentuk Sifat Imaniyyah. Bandung: Al-Ishlah Press, t,t.

Anonim. Direktori Kasus-Kasus Aliran, Pemikiran, Paham, dan Gerakan Keagamaan di Indonesia. Jakarta: Badan Litbang dan Diklat Kementerian Agama, 2010.

Basidin Mizal. "Pendidikan dalam Keluarga”. Jurnal Ilmiah Peuradeun, Vol. 2, No. 3, September 2014.

Binti Qoni'ah. “Pendidikan Anak dalam Perspektif Hadis”. Disertasi, Sekolah Pascasarjana UIN Syarif Hidyatulllah Jakarta, 2007. 
Budimansyah. “Gerakan Jama'ah Tabligh Dalam Tinjauan Maqashid AlDin”. Al-'Adalah, Vol. X, No. 3 Januari 2012.

Daar an-Nadwah al-'Aalamiyah li asy-Sabaab al-Islamy. al-Mausu'ah al-Muyassarah fii al-Adyaan wa al-Madzaahib wa al-Ahzaab alMu'aashirah. Ar-Riyaadh: Daar an-Nadwah al-'Aalamiyyah li ath-Thibaa'ah, $1420 \mathrm{H} / 1998 \mathrm{M}$.

Elmanora, dkk. "Gaya Pengasuhan dan Perkembangan Sosial Emosi Anak Usia Sekolah pada Keluarga Petani Kayu Manis”, dalam Jurnal Ilmu, Keluarga dan Konseling, Vol. 5, No. 2, Agustus 2012.

Eva F Nisa. "Insight Into the Lives of Indonesian Female Tablighi Jama'at”. Modern Asian Studies, Vol. 48, No. 2, 2014,

Farish A Noor. Islam on the Move: The Tablighi Jama'at in Southeast Asia. Amsterdam: Amsterdam University Press, 2012.

Hamid Patilima. Metode Penelitian Kualitatif. Bandung: Alfabeta, Edisi Revisi, 2013.

Herlina Hasan Khalida. Membangun Pendidikan Islami di Rumah. Jakarta: Redaksi Kunci Iman, 2014

Ida dan Ah. Bambang. Masturah: Usaha Dakwah di Kalangan Wanita Muslimah (buku, tidak diterbitkan, 2010.

Iskandar. Metode Penelitian Pendidikan dan Sosial (kualitatif dan Kuantitatif). Jakarta: Gaung Persada Press, 2009.

Itaf Bareeq Mahya. Mendidik Anak Ala Rasulullah Sejak dalam Kandungan Sampai Usia 18 Tahun. Klaten: Abata Press, 2014.

Juliah. “Analisis Kemampuan Komunikasi Matematis Siswa Sekolah Dasar”. Tesis, Universitas Pendidikan Indonesia, 2012.

Juliani Prasetyaningrum. "Pola Asuh dan Karakter Anak dalam Perspektif Islam". Prosiding Seminar Nasional Psikologi Islam: Aplikasi Psikologi Islami dalam Pendidikan Karakter, Fakultas Psikologi, UMS, 2012. 
Kamaruzzaman Bustamam Ahmad. "The History of Jamaah Tabligh in Southeast Asia: The Role of Islamic Sufism in Islamic Revival”. Al-Jamiah, Vol. 46, No. 2, 2008.

Lembaga Pengkajian dan Penelitian WAMY. Gerakan Keagamaan dan Pemikiran. Jakarta: Al-I’tishom Cahaya Umat, Cet. 6, 2006.

Lexy J Moleong. Metodologi Penelitian Kualitatif. Bandung: PT. Remaja Rosdakarya, Cet. XXV, 2008.

Peraturan Menteri Sosial Republik Indonesia Nomor 30/HUK/2011, Standar Nasional Pengasuhan Anak Untuk Lembaga Kesejahteraan Sosial Anak. Jakarta: Berita Negara Republik Indonesia Tahun 2011 Nomor 303.

Pupu Saeful Rahmat. “Penelitian Kualitatif”. Equilibrium, Vol. 5, No. 9, Januari-Juni 2009.

Rida Nurhayanti, Dkk. “Tipe Pola Asuh Orang Tua yang Berhubungan dengan Prilaku Bullying di SMA Kabupaten Semarang”. Jurnal Keperawatan Jiwa, Vol. 1, No. 1, Mei 2013.

Riduwan. Metode dan Teknik Menyusun Proposal Penelitian. Bandung: Alfabeta, 2010.

Sugiyono. Memahami Penelitian Kualitatif. Bandung: CV. Alfabeta, Cet. 9, 2014.

. Metode Penelitian Pendidikan: Pendekatan Kuantitatif, Kualitatif, dan $R$ \& D. Bandung: CV. Alfabeta, 2006.

Syaiful Bahri Djamarah. Pola Asuh Orang Tua dan Komunikasi dalam Keluarga. Jakarta: PT. Rineka Cipta, 2014.

Undang-Undang Republik Indonesia Nomor 35 tahun 2014. Perubahan atas Undang-Undang Nomor 23 Tahun 2002 Tentang Perlindungan Anak. Jakarta: Lembaran Negara Republik Indonesia Tahun 2014 Nomor 297. 